\title{
BMJ Global Health Evaluating access to essential medicines for treating childhood cancers: a medicines availability, price and affordability study in New Delhi, India
}

\author{
Neha Faruqui, ${ }^{1,2}$ Alexandra Martiniuk, ${ }^{1,2}$ Abhishek Sharma, ${ }^{\oplus 3,4}$ Chanchal Sharma, ${ }^{5}$ \\ Bhumika Rathore, ${ }^{6}$ Ramandeep Singh Arora, ${ }^{6,7}$ Rohina Joshi ${ }^{1,2}$
}

\begin{abstract}
To cite: Faruqui N, Martiniuk A, Sharma A, et al. Evaluating access to essential medicines for treating childhood cancers: a medicines availability, price and affordability study in New Delhi, India. BMJ Glob Health 2019:4:e001379. doi:10.1136/ bmjgh-2018-001379
\end{abstract}

Handling editor Sanni Yaya

- Additional material is published online only. To view please visit the journal online (http://dx.doi.org/10.1136/ bmjgh-2018-001379).

Received 23 December 2018 Revised 12 March 2019 Accepted 16 March 2019

Check for updates

(c) Author(s) (or their employer(s)) 2019. Re-use permitted under CC BY-NC. No commercial re-use. See rights and permissions. Published by BMJ.

For numbered affiliations see end of article.

Correspondence to

Neha Faruqui;

neha.faruqui@sydney.edu.au

\section{ABSTRACT}

Introduction Limited access to essential medicines (EMs) for treating chronic diseases is a major challenge in lowincome and middle-income countries. Although India is the largest manufacturer of generic medicines, there is a paucity of information on availability, price and affordability of anti-neoplastic EMs, which this study evaluates.

Methods Using a modified WHO/Health Action International methodology, data were collected on availability and price of 33 strength-specific anti-neoplastic EMs and 4 non-cancer EMs. Seven 'survey anchor' hospitals (4 public and 3 private) and 32 private-sector retail pharmacies were surveyed. Median price ratios (MPRs) were calculated by comparing consumer prices with international reference prices (IRPs).

Results On average, across survey anchor areas (hospital and private-sector retail pharmacies combined), the mean availability of anti-neoplastic EMs and noncancer medicines was $70 \%$ and $100 \%$, respectively. Mean availability of anti-neoplastic EMs was $38 \%$ in private-sector retail pharmacies, $43 \%$ in public hospital pharmacies and $71 \%$ in private hospital pharmacies. Median MPR of lowest-priced generic versions was 0.71 in retail pharmacies. The estimated cost of chemotherapy medicines needed for treating a $30 \mathrm{~kg}$ child with standardrisk leukaemia was INR 27850 (US\$442) and INR 17500 (US\$278) for Hodgkin's lymphoma, requiring 88 and 55 days' wages, respectively, for the lowest paid government worker.

Conclusion Most anti-neoplastic EMs are found in survey anchor areas, however, mean availability was less than non-cancer medicines; not meeting the WHO target of $80 \%$. Medicine prices were relatively low in New Delhi compared with IRPs. However, the cost of chemotherapy medicines seems unaffordable in the local context.

\section{INTRODUCTION}

Cancer is the fifth leading cause of death in children aged 5-14 years in India, ${ }^{1}$ where leukaemia and lymphoma are the two most common cancers. ${ }^{2}$ Treating children with cancer has a high survival rate $(80 \%$ in high-income countries) with early detection,

\section{Key questions}

What is already known?

- Limited availability and poor affordability of essential medicines is a major public health concern globally, and there is limited information about access to anti-neoplastic essential medicines.

What are the new findings?

- Mean availability of anti-neoplastic essential medicines across all survey anchor areas (hospital and private-sector retail pharmacies combined) was $70 \%$; less than the WHO availability target of $80 \%$.

- The median price ratio in comparison with international reference prices was less than 4 , implying medicines in India are less expensive compared with international standards. However, chemotherapy medicines are unaffordable for the lowest paid government worker in India.

What do the new findings imply?

- Low availability and poor affordability highlight the need to streamline public-sector and private-sector medicine procurement and supply systems.

- Government insurance schemes and discount-pharmacy initiatives should expand the inclusion of essential anti-neoplastic medicines, as a way towards limiting the catastrophic out-of-pocket expenditure associated with cancer treatment.

multimodal treatment and robust supportive care delivered at the appropriate time. ${ }^{3}$ The 5 -year survival rate in India is $37 \%-40 \%$, and to increase this, equitable access to affordable healthcare including essential medicines is one of the challenges. ${ }^{4}$ In India, healthcare is provided by both the public and private health sectors. While public hospitals offer free or subsidised treatment including essential medicines, the high patient caseloads, underfunding and inefficient medicine distribution systems are barriers to consistent service provision. ${ }^{5}$ When medicines are 
unavailable in the public sector, patients either must wait for unknown periods for medicines to be in stock or purchase them out-of-pocket at the private-sector retail pharmacies. This can also drive patients to seek treatment from private hospitals, leading to even greater out-of-pocket expenditures. ${ }^{67}$

In 2011, the WHO Expert Committee argued for the inclusion of selected chemotherapy medications for childhood cancers in the children's essential medicines list (EMLc). ${ }^{8}$ In addition, the Essential Medicines Working Group of Société Internationale d'Oncologie Pédiatrique (SIOP) helped identify those medicines that are required to treat children with cancer in low-income and middle-income countries (LMICs), where $80 \%$ of the childhood cancer burden exists. ${ }^{8}$ They considered issues such as resource limitations, health disparities and economic constraints while identifying the basket of essential medicines. ${ }^{9}$ One of the aims of the EMLc is to serve as a guide for LMICs to develop their national lists with the goal of improving the accessibility, availability and affordability of essential medicines needed to treat curable childhood cancers.

The WHO/Health Action International (HAI) developed a methodology to measure the availability, price and affordability of essential medicines. ${ }^{10}$ The methodology uses the Management Sciences for Health (MSH) international reference prices which are widely accepted as the reference standard, reporting actual procurement prices obtained through international tender prices and non-profit suppliers to LMICs. ${ }^{11}$ Given the importance of medicine availability and prices in patient access, WHO set a target that essential medicines should be available in $80 \%$ of the facilities across public and private sectors. ${ }^{12}$ Furthermore, the current Director General of WHO, Tedros Adhanom Ghebreyesus, reaffirmed that "No family should endure financial hardship for out-of-pocket payments for the purchase of medicines to treat their loved ones, and no man, woman or child should die simply because they cannot access the life-saving medicines they need". ${ }^{13}$

India updated its National EMLc in 2011 to include anti-neoplastic medicines and promote generic production of these medicines. ${ }^{14}$ While several WHO/HAI surveys have been conducted to evaluate medicine access across the regions and therapeutic areas, none have evaluated essential medicines for childhood cancers in India or elsewhere. The National EMLc recommends a basket of essential medicines, and it is important to understand if these medicines are readily accessible to patients. Therefore, the objective of this study was to assess the availability, price and affordability of essential medicines for treating childhood cancers in New Delhi, India.

\section{METHODS}

Using a modified version of the WHO/HAI methodology, a cross-sectional survey was conducted to assess availability, price and affordability of childhood cancer medicines in the public and private healthcare sectors in India. Written informed consent was obtained from 32 retail pharmacies, and verbal consent from 4 public hospitals and 3 private hospitals prior to data collection. Due to the heavy work flow in the hospital pharmacies (limited opening hours and few support staff), it was logistically difficult to collect written informed consent. Hence, a modification was sought by the ethics committee to collect verbal consent where written consent was not possible, and this was approved. Verbal consent was thus taken and recorded in the data collector's field notes. Names of all surveyed pharmacies and hospitals have been de-identified prior to analysis to ensure privacy.

\section{Patient and public involvement}

No patients were involved in this study. We have provided authors' email addresses in the Participant Information Sheet to all pharmacists if they would like the results of this study.

\section{Sampling}

\section{Survey facilities}

We purposively selected a sample of eight hospitals treating childhood cancers in New Delhi that were representative of the public $(n=4)$ and private $(n=4)$ sectors, annual patient load (low or high) and geographical areas (figure 1). This sampling technique allowed for maximum representative variation in measuring the availability and price of essential medicines in New Delhi. These eight hospitals served as the 'survey anchors'. For each survey anchor, we surveyed the hospital pharmacy (one hospital did not participate) and private-sector retail pharmacies near the chosen survey anchor hospital. Since there is no publicly available comprehensive list of retail pharmacies in Delhi, Google maps was used to identify pharmacies in each survey anchor area. Data collectors located the pharmacies in-person and scoped the survey vicinity first, followed by random selection. This selection involved data collectors to stand outside each hospital entrance, as a caregiver of a patient would, identify all pharmacies seen within an eye-view distance and randomly select five of them. Although retail pharmacies were identified up to $1 \mathrm{~km}$ from the hospital, some survey anchor areas had less than five retail pharmacies open and some pharmacists did not consent to participate in the study, yielding a total sample size of 32 retail pharmacies.

\section{Survey medicines}

The WHO 2017 EMLc Model List ${ }^{15}$ recommends 28 anti-neoplastic and supportive care essential medicines of which 20 anti-neoplastic medicines were selected that came in 24 dosage forms (route of administration) and 33 specific strengths. See table 1 for the complete list of medicines. To ensure that the survey medicine list was comprehensive, the WHO EMLc was compared with the EMLc developed by SIOP, ${ }^{9}$ India's 2011 National EMLc, ${ }^{16}$ India's 2015 National EML ${ }^{17}$ and Delhi's 2016 $\mathrm{EML}^{18}$ (online supplementary table 1A). Furthermore, in accordance to the WHO/HAI methodology, four 


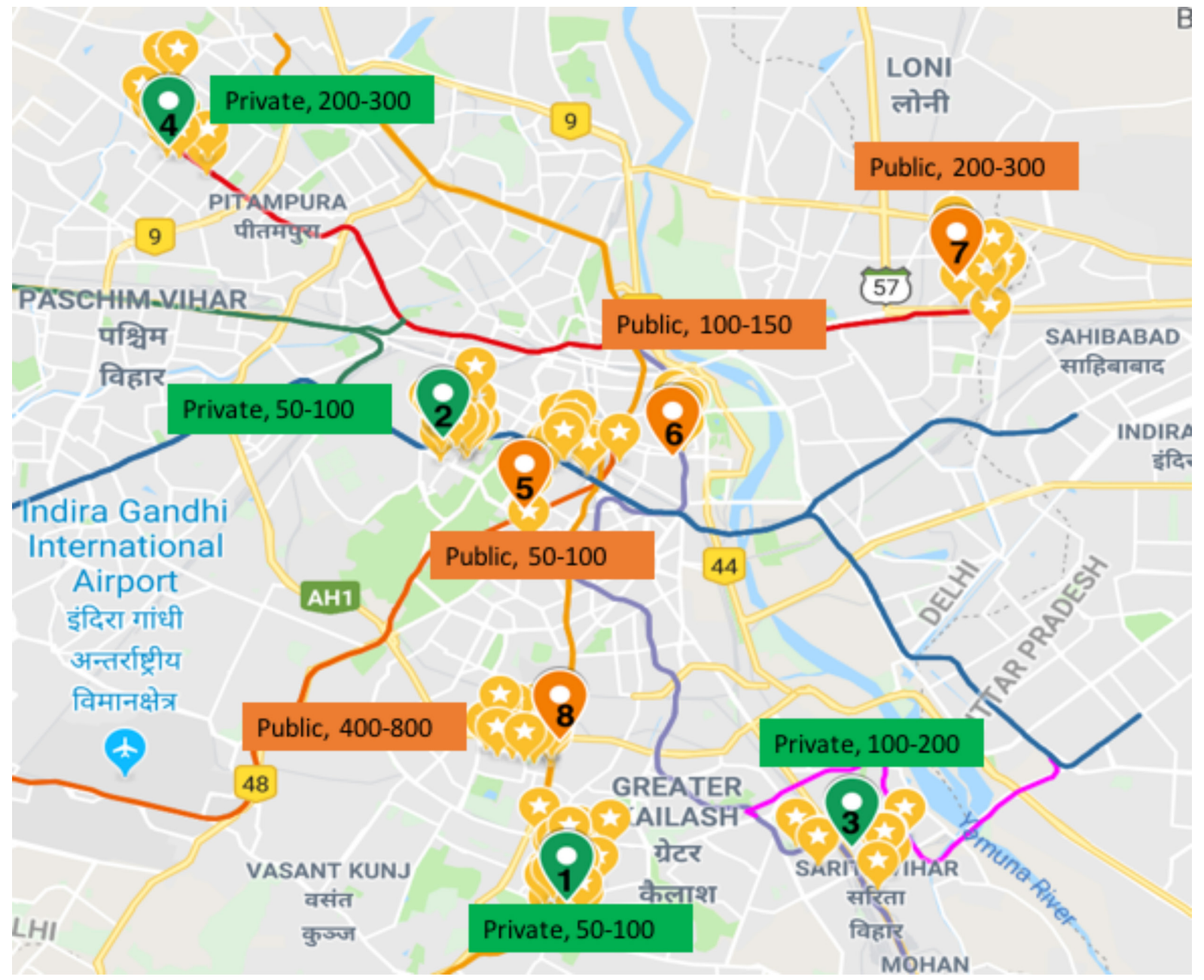

Public survey anchors

Private survey anchors

Pharmacies identified

Figure 1 Map of hospitals and surrounding pharmacies (survey anchor areas) in New Delhi; hospital type and annual caseload shown next to each numbered survey anchor area.

commonly used non-cancer essential medicines (amoxicillin, ciprofloxacin, metformin and omeprazole) were also surveyed as an internal control comparator to evaluate if access to cancer medicines differs from other essential medicines.

Each medicine surveyed had a specific strength, dosage form, standard pack size of 10 if capsule/tablet and three medicine versions: (1) originator brand, also known as the innovator brand that was the first to receive market authorisation, (2) most-sold generic brands and (3) lowest-priced generic brands. Since there is no publicly available list of originator brands used in childhood cancer treatment, an attempt was made at identifying them prior to the survey through online searches, contacting experts in the pharmaceutical field and checking the US Food and Drug Administration website for any records. See online supplementary table 1A for the list of originator brands identified.

\section{Data collection and analysis}

A feasibility study was conducted to plan the logistics for data collection. This included understanding the retail pharmacy peak hours, roster of pharmacists, paediatric oncology treatment days and clinic timings for when patients were most likely to receive prescriptions. Trained data collectors visited the pharmacies, met the pharmacist available at the facility on the day of survey and had them fill a standardised paper form developed by the authors. CS and NF inspected the physical availability of the survey medicines and confirmed the price stated by the pharmacist by re-checking the pack and/or by reviewing the price records. 
Table 1 Availability of essential medicines (generic or originator brand version combined) by facility type and survey anchor areas in Delhi

\begin{tabular}{|c|c|c|c|c|}
\hline Anti-neoplastic essential medicines & $\begin{array}{l}\% \text { Retail pharmacies } \\
(n=32)\end{array}$ & $\begin{array}{l}\% \text { Private hospital } \\
\text { pharmacies }(n=3)\end{array}$ & $\begin{array}{l}\% \text { Public hospital } \\
\text { pharmacies }(n=4)\end{array}$ & $\begin{array}{l}\% \text { Survey anchor } \\
\text { areas }(n=7)\end{array}$ \\
\hline Asparaginase, powder inj, $10000 \mathrm{IU}$ in vial & 19 & 100 & 100 & 100 \\
\hline Bleomycin, powder inj, $15 \mathrm{mg}$ & 53 & 100 & 75 & 100 \\
\hline Carboplatin, inj, $150 \mathrm{mg} / 15 \mathrm{~mL}$ & 47 & 100 & 50 & 100 \\
\hline Carboplatin, inj, $450 \mathrm{mg} / 45 \mathrm{~mL}$ & 44 & 100 & 50 & 86 \\
\hline Carboplatin, inj, $50 \mathrm{mg} / 5 \mathrm{~mL}$ & 0 & 0 & 0 & 0 \\
\hline Carboplatin, inj, $600 \mathrm{mg} / 60 \mathrm{~mL}$ & 0 & 0 & 0 & 0 \\
\hline Carboplatin-no specific strength & 47 & 100 & 75 & 100 \\
\hline Cisplatin, inj, $100 \mathrm{mg} / 100 \mathrm{~mL}$ & 0 & 0 & 0 & 0 \\
\hline Cisplatin, inj, $50 \mathrm{mg} / 50 \mathrm{~mL}$ & 44 & 100 & 75 & 100 \\
\hline Cisplatin-no specific strength & 44 & 100 & 75 & 100 \\
\hline Cyclophosphamide, powder inj, $500 \mathrm{mg}$ in vial & 47 & 100 & 0 & 86 \\
\hline Cyclophosphamide, tab, $25 \mathrm{mg}$ & 0 & 0 & 0 & 0 \\
\hline Cytarabine, powder inj, $100 \mathrm{mg}$ in vial & 31 & 100 & 75 & 86 \\
\hline Dacarbazine, powder inj, $100 \mathrm{mg}$ in vial & 16 & 0 & 50 & 29 \\
\hline Dactinomycin, powder inj, $500 \mu \mathrm{g}$ in vial & 28 & 100 & 25 & 57 \\
\hline Daunorubicin, powder inj, $50 \mathrm{mg}$ in vial & 0 & 0 & 0 & 0 \\
\hline Dexamethasone, oral liquid, $2 \mathrm{mg} / 5 \mathrm{~mL}$ & 0 & 0 & 0 & 0 \\
\hline Doxorubicin, powder inj, $10 \mathrm{mg}$ & 31 & 100 & 50 & 86 \\
\hline Doxorubicin, powder inj, $50 \mathrm{mg}$ & 47 & 100 & 75 & 100 \\
\hline Doxorubicin-no specific strength & 47 & 100 & 75 & 100 \\
\hline Etoposide, cap, $100 \mathrm{mg}$ & 0 & 0 & 0 & 0 \\
\hline Etoposide, inj, $100 \mathrm{mg}$ & 38 & 67 & 50 & 100 \\
\hline Ifosfamide, powder inj, $500 \mathrm{mg}$ & 0 & 0 & 0 & 0 \\
\hline Ifosfamide, powder inj, $2 \mathrm{~g}$ vial & 19 & 67 & 0 & 57 \\
\hline Ifosfamide, powder inj, $1 \mathrm{~g}$ & 28 & 67 & 50 & 86 \\
\hline Ifosfamide, powder inj-no specific strength & 34 & 67 & 50 & 88 \\
\hline Mercaptopurine, tab, $50 \mathrm{mg}$ & 56 & 100 & 25 & 100 \\
\hline Methotrexate, powder inj, $50 \mathrm{mg}$ in vial & 78 & 100 & 75 & 100 \\
\hline Methotrexate, tab, $2.5 \mathrm{mg}$ & 84 & 67 & 75 & 100 \\
\hline Paclitaxel, powder inj, $6 \mathrm{mg} / \mathrm{mL}$ & 16 & 100 & 0 & 57 \\
\hline Prednisolone, oral liquid, $5 \mathrm{mg} / \mathrm{mL}$ & 88 & 100 & 25 & 100 \\
\hline Prednisolone, tab, $25 \mathrm{mg}$ & 0 & 0 & 0 & 0 \\
\hline Prednisolone, tab, $5 \mathrm{mg}$ & 91 & 100 & 75 & 100 \\
\hline Prednisolone, tab-no specific strength & 91 & 100 & 75 & 100 \\
\hline Thioguanine, solid oral dosage form, $40 \mathrm{mg}$ & 34 & 67 & 25 & 43 \\
\hline Vinblastine, powder inj, $10 \mathrm{mg}$ (sulfate) in vial & 41 & 100 & 50 & 100 \\
\hline Vincristine, powder inj, $1 \mathrm{mg}$ & 47 & 100 & 75 & 100 \\
\hline Vincristine, powder inj, $5 \mathrm{mg}$ & 0 & 0 & 0 & 0 \\
\hline Vincristine, powder inj-no specific strength & 47 & 100 & 75 & 100 \\
\hline Mean (SD) & $38(28)$ & $71(42)$ & $43(33)$ & $70(41)$ \\
\hline \multicolumn{5}{|l|}{ Non-cancer essential medicines } \\
\hline Amoxicillin $250 \mathrm{mg}$, cap/tab & 84 & 0 & 50 & 100 \\
\hline Ciprofloxacin 500 mg, cap/tab & 100 & 100 & 50 & 100 \\
\hline Metformin $500 \mathrm{mg}$, cap/tab & 100 & 67 & 100 & 100 \\
\hline Omeprazole 20 mg, cap/tab & 100 & 67 & 75 & 100 \\
\hline Mean (SD) & $96(8)$ & $58(42)$ & $69(24)$ & 100 \\
\hline
\end{tabular}

Mean percentages were calculated using all specific strengths, except six which had more than one strength, hence were instead calculated as 'no specific strength' cap, capsule; inj, injection; tab, tablet. 


\section{Availability}

The availability of survey medicines was assessed by inspecting the different versions (generic or originator) and strengths of medicines. Medicine availability was calculated as percentage of survey anchor areas (ie, hospital and private-sector retail pharmacies combined) where a given medicine was available on the day of survey. Medicine availability was also expressed as percentage of pharmacies (retail/hospital) stocking a given medicine. If more than one strength was listed on the WHO EMLc for a particular medicine (6 out of 33 survey medicines), it was considered available as long as at least one of the strengths was available.

\section{Price}

As government hospitals provide free medicines to patients, data regarding price were only collected from private retail pharmacies $(n=32)$ and private hospital pharmacies $(n=2)$. Prices paid by the consumer at private retail pharmacies (which may be maximum retail price or discounted price) were obtained through available price lists. Prices were recorded for each version (originator brand, most-sold generic and lowest-priced generic) for each medicine in Indian rupees (INR). For solid oral dosage medicines, price was adjusted to a pack size of 10 capsules/tablets, and for injectables we collected price per vial/ampoule. The median price ratio (MPR) was calculated to evaluate the consumer price in Delhi compared with international reference prices. WHO set a benchmark that no patient purchasing medicines in the private sector should pay more than four times the international reference price. ${ }^{19}$ MPR was calculated using the following formula:

$$
\text { Price ratio }=\frac{\text { Local consumer price (USD) }}{\text { International reference price (USD) }}
$$

Prices collected from two private hospital pharmacies were only for the most-sold generic versions. Additional data were collected on public-sector procurement prices from two public hospitals that procured medicines through a Central Procurement Agency and from one public hospital that procured through a private-sector wholesaler at $23 \%$ off the maximum retail price. Prices were also sought on the Jan Aushadhi website (government initiative to provide generic medicines at cheaper prices). ${ }^{20}$

\section{Affordability}

Affordability was calculated for the two most common cancers in India: acute lymphoblastic leukaemia and Hodgkin's lymphoma. The WHO/HAI method suggests calculating affordability of medicines for chronic diseases using the cost of 1 month's supply of medicines needed for treatment as a reference. However, cancer treatment is based on the duration of therapy depending on risk and disease (on average 2.5 years for acute lymphoblastic leukaemia and 4-6 months for Hodgkin's lymphoma). Therefore, our affordability analysis used the median consumer price of the most-sold generic version to calculate the cost of medicines needed for treating a standard $30 \mathrm{~kg}$ child with body surface area of $1 \mathrm{~m}^{2}$, who is either diagnosed with standard/high-risk B-cell precursor acute lymphoblastic leukaemia or early/ advanced stage Hodgkin's lymphoma, using the Indian Paediatric Oncology Group (InPOG) protocols. The number of days' wages was calculated by dividing the total cost of chemotherapy for each cancer by the daily wage of the lowest-paid unskilled government worker in India, that is, INR $318 .^{21}$ We also calculated the cost of chemotherapy medicines as a percentage of India's 2017 per-capita income. Currency conversion used at the time of data collection and analysis was INR $63=\mathrm{US} \$ 1{ }^{22}$ All data were entered and analysed in Microsoft Excel V.15.

\section{RESULTS \\ Availability}

The mean availability of anti-neoplastic medicines across seven survey anchor areas (hospital and retail pharmacies combined) was $70 \%$ (table 1). Strength-specific medicines which were unavailable in any pharmacy were available in alternative doses and strengths, which were not on the EMLc (eg, daunorubicin is available in alternative strength of $20 \mathrm{mg}$ ). Mean availability of anti-neoplastic medicines was $43 \%$ and $71 \%$, respectively, in the public-sector and private-sector hospital pharmacies. In private-sector retail pharmacies, mean availability of anti-neoplastic medicines in either generic or originator brand version was $38 \%$. See table 1 for mean availability of non-cancer medicines.

Methotrexate $(2.5 \mathrm{mg}$ tablet and $50 \mathrm{mg}$ injection) and prednisolone $(5 \mathrm{mg} / \mathrm{mL}$ oral liquid and $5 \mathrm{mg}$ tablet) were available in over $80 \%$ of retail pharmacies. Twenty-seven out of the 33 anti-neoplastic medicines were available in less than $50 \%$ of retail pharmacies, and 10 of these were not available in any pharmacy.

Originator brands were available for five anti-neoplastic medicines and none of the non-cancer medicines. The percentage availability in retail pharmacies was cyclophosphamide, powder inj, $500 \mathrm{mg}$ in vial (25\%); cytarabine, powder inj, $100 \mathrm{mg}$ in vial (3\%); doxorubicin, powder inj, $10 \mathrm{mg}$ in vial $(6 \%)$; doxorubicin, powder inj, $50 \mathrm{mg}$ in vial (9\%); and ifosfamide, powder inj, $2 \mathrm{~g}$ in vial $(16 \%)$.

\section{Prices}

Retail pharmacies $(\mathrm{n}=32)$

Median MPR for anti-neoplastic medicines of the mostsold generic, lowest-priced generic and originator brand was $0.74,0.71$ and 1.00 , respectively (table 2). Median MPR for non-cancer medicines of the most-sold and lowest-priced generic was 1.92 and 1.90, respectively. All MPR for both anti-neoplastic and non-cancer medicines was less than 4. Data on the most-sold and lowest-priced generic versions were collected for 23 strength-specific anti-neoplastic medicines (as 10 were unavailable), where 20 of these medicines had the same median price for the 
BMJ Global Health

Table 2 Price paid by consumers at private-sector retail pharmacies for each product version of surveyed medicines and their MPRs

\begin{tabular}{|c|c|c|c|c|c|}
\hline Anti-neoplastic essential medicines & $\begin{array}{l}\text { Product } \\
\text { type }\end{array}$ & $\begin{array}{l}\text { Median price } \\
\text { (INR) }\end{array}$ & $\begin{array}{l}\text { Minimum price } \\
\text { (INR) }\end{array}$ & $\begin{array}{l}\text { Maximum price } \\
\text { (INR) }\end{array}$ & MPR \\
\hline \multirow[t]{3}{*}{ Asparaginase, powder inj, $10000 \mathrm{IU}$ in vial } & OB & - & - & - & - \\
\hline & MSG & 1500 & 1300 & 1564 & 0.45 \\
\hline & LPG & 1500 & 952 & 1564 & 0.45 \\
\hline \multirow[t]{3}{*}{ Bleomycin, powder inj, $15 \mathrm{mg}$} & OB & - & - & - & - \\
\hline & MSG & 540 & 364 & 650 & 0.71 \\
\hline & LPG & 530 & 364 & 595 & 0.69 \\
\hline \multirow[t]{3}{*}{ Carboplatin, inj, $150 \mathrm{mg} / 15 \mathrm{~mL}$} & $\mathrm{OB}$ & - & - & - & - \\
\hline & MSG & 730 & 600 & 850 & 0.78 \\
\hline & LPG & 680 & 600 & 850 & 0.72 \\
\hline \multirow[t]{3}{*}{ Carboplatin, inj, $450 \mathrm{mg} / 45 \mathrm{~mL}$} & OB & - & - & - & - \\
\hline & MSG & 2000 & 1650 & 2466 & 0.92 \\
\hline & LPG & 2000 & 1650 & 2466 & 0.92 \\
\hline \multirow[t]{3}{*}{ Cisplatin, inj, $50 \mathrm{mg} / 50 \mathrm{~mL}$} & OB & - & - & - & - \\
\hline & MSG & 302 & 280 & 336 & 0.80 \\
\hline & LPG & 302 & 250 & 336 & 0.80 \\
\hline \multirow[t]{3}{*}{ Cyclophosphamide, powder inj, $500 \mathrm{mg}$ in vial } & OB & 76 & 60 & 76 & 0.15 \\
\hline & MSG & 65 & 40 & 76 & 0.13 \\
\hline & LPG & 65 & 40 & 76 & 0.13 \\
\hline \multirow[t]{3}{*}{ Cytarabine, powder inj, $100 \mathrm{mg}$ in vial } & OB & 200 & 190 & 200 & 1.02 \\
\hline & MSG & 150 & 100 & 200 & 0.77 \\
\hline & LPG & 150 & 100 & 200 & 0.77 \\
\hline \multirow[t]{3}{*}{ Dacarbazine, powder inj, $100 \mathrm{mg}$ in vial } & OB & - & - & - & - \\
\hline & MSG & 250 & 250 & 250 & NA \\
\hline & LPG & 250 & 250 & 250 & NA \\
\hline \multirow[t]{3}{*}{ Dactinomycin, powder inj, $500 \mu \mathrm{g}$ in vial } & OB & - & - & - & - \\
\hline & MSG & 442 & 350 & 445 & 0.81 \\
\hline & LPG & 442 & 350 & 445 & 0.81 \\
\hline \multirow[t]{3}{*}{ Doxorubicin, powder inj, $10 \mathrm{mg}$} & OB & 158 & 140 & 175 & 1.18 \\
\hline & MSG & 148 & 120 & 180 & 1.10 \\
\hline & LPG & 148 & 120 & 180 & 1.10 \\
\hline \multirow[t]{3}{*}{ Doxorubicin, powder inj, 50 mg } & OB & 750 & 700 & 1276 & 1.64 \\
\hline & MSG & 510 & 300 & 1276 & 1.12 \\
\hline & LPG & 510 & 300 & 1276 & 1.12 \\
\hline \multirow[t]{3}{*}{ Etoposide, inj, $100 \mathrm{mg} / 5 \mathrm{~mL}$} & OB & - & - & - & - \\
\hline & MSG & 173 & 150 & 200 & 1.40 \\
\hline & LPG & 173 & 140 & 200 & 1.40 \\
\hline \multirow[t]{3}{*}{ Ifosfamide, powder inj, $2 \mathrm{~g}$ vial } & OB & 950 & 350 & 1131 & 0.31 \\
\hline & MSG & 781 & 350 & 1015 & 0.26 \\
\hline & LPG & 781 & 350 & 1015 & 0.26 \\
\hline \multirow[t]{3}{*}{ Ifosfamide, powder inj, $1 \mathrm{~g}$} & OB & - & - & - & - \\
\hline & MSG & 450 & 300 & 565 & 0.66 \\
\hline & LPG & 450 & 300 & 565 & 0.66 \\
\hline \multirow[t]{3}{*}{ Mercaptopurine, tab, $50 \mathrm{mg}$} & OB & - & - & - & - \\
\hline & MSG & 69 & 55 & 80 & 0.05 \\
\hline & LPG & 69 & 55 & 80 & 0.05 \\
\hline
\end{tabular}


Table 2 Continued

\begin{tabular}{|c|c|c|c|c|c|}
\hline Anti-neoplastic essential medicines & $\begin{array}{l}\text { Product } \\
\text { type }\end{array}$ & $\begin{array}{l}\text { Median price } \\
\text { (INR) }\end{array}$ & $\begin{array}{l}\text { Minimum price } \\
\text { (INR) }\end{array}$ & $\begin{array}{l}\text { Maximum price } \\
\text { (INR) }\end{array}$ & MPR \\
\hline \multirow[t]{3}{*}{ Methotrexate, powder inj, $50 \mathrm{mg}$ in vial } & OB & - & - & - & - \\
\hline & MSG & 92 & 50 & 92 & NA \\
\hline & LPG & 92 & 40 & 92 & NA \\
\hline \multirow[t]{3}{*}{ Methotrexate, tab, $2.5 \mathrm{mg}$} & $\mathrm{OB}$ & - & - & - & - \\
\hline & MSG & 45 & 40 & 55 & 0.45 \\
\hline & LPG & 45 & 40 & 55 & 0.45 \\
\hline \multirow[t]{3}{*}{ Paclitaxel, powder inj, 6 mg/mL } & OB & - & - & - & - \\
\hline & MSG & 900 & 450 & 910 & 0.04 \\
\hline & LPG & 885 & 450 & 910 & 0.04 \\
\hline \multirow[t]{3}{*}{ Prednisolone, oral liquid, $5 \mathrm{mg} / \mathrm{mL}$} & OB & - & - & - & - \\
\hline & MSG & 20 & 20 & 40 & NA \\
\hline & LPG & 20 & 20 & 40 & NA \\
\hline \multirow[t]{3}{*}{ Prednisolone, tab, $5 \mathrm{mg}$} & OB & - & - & - & - \\
\hline & MSG & 6 & 5 & 6 & 0.86 \\
\hline & LPG & 6 & 5 & 6 & 0.82 \\
\hline \multirow[t]{3}{*}{ Thioguanine, solid oral dosage form, $40 \mathrm{mg}$} & $\mathrm{OB}$ & - & - & - & - \\
\hline & MSG & 270 & 148 & 300 & 0.06 \\
\hline & LPG & 270 & 148 & 300 & 0.06 \\
\hline \multirow[t]{3}{*}{ Vinblastine, powder inj, $10 \mathrm{mg}$ (sulfate) in vial } & OB & - & - & - & - \\
\hline & MSG & 200 & 160 & 282 & 1.24 \\
\hline & LPG & 200 & 160 & 282 & 1.24 \\
\hline \multirow[t]{3}{*}{ Vincristine, powder inj, $1 \mathrm{mg}$} & OB & - & - & - & - \\
\hline & MSG & 48 & 40 & 75 & 0.23 \\
\hline & LPG & 48 & 35 & 75 & 0.23 \\
\hline Median MPR of MSG & & & & & 0.74 \\
\hline Median MPR of LPG & & & & & 0.71 \\
\hline Median MPR of OB & & & & & 1.00 \\
\hline \multicolumn{6}{|l|}{ Non-cancer essential medicines* } \\
\hline \multirow[t]{3}{*}{ Amoxicillin $250 \mathrm{mg}$ tab/cap } & OB & - & - & - & - \\
\hline & MSG & 22 & 19 & 27 & 2.22 \\
\hline & LPG & 22 & 9 & 27 & 2.22 \\
\hline \multirow[t]{3}{*}{ Ciprofloxacin 500 mg, cap/tab } & $\mathrm{OB}$ & - & - & - & - \\
\hline & MSG & 37 & 30 & 49 & 1.57 \\
\hline & LPG & 37 & 30 & 49 & 1.57 \\
\hline \multirow[t]{3}{*}{ Metformin 500 mg cap/tab } & $\mathrm{OB}$ & - & - & - & - \\
\hline & MSG & 15 & 10 & 19 & 1.61 \\
\hline & LPG & 15 & 9 & 15 & 1.59 \\
\hline \multirow[t]{3}{*}{ Omeprazole 20 mg, cap/tab } & OB & - & - & - & - \\
\hline & MSG & 25 & 22 & 36 & 2.85 \\
\hline & LPG & 25 & 20 & 33 & 2.83 \\
\hline Median MPR of MSG & & & & & 1.92 \\
\hline Median MPR of LPG & & & & & 1.90 \\
\hline
\end{tabular}

*Median MPR for OB was not calculated as OBs were unavailable.

LPG, lowest-priced generic; MPR, median price ratio; MSG, most-sold generic; OB, originator brand.

most-sold and lowest-priced generics, and 3 had a greater most-sold price compared with the lowest-priced generic (INR 10-50 US\$0.15-0.73 more expensive). See table 2.
Five anti-neoplastic originator brands were 1.2-1.4 times more expensive than their most-sold and lowest-priced generic counterparts. The highest consumer price 
difference across all surveyed retail pharmacies was INR 976 (US\$14) for doxorubicin $50 \mathrm{mg}$ injection between lowest-priced generic Doxoruba (INR 300 । US\$4) and originator brand Adriamycin (INR 1276 I US\$19), the originator brand being 4.3 times more expensive than the lowest-priced generic. The lowest MPR was 0.04 for generic versions of paclitaxel $6 \mathrm{mg} / \mathrm{mL}$ and highest MPR of 1.64 was for originator brand doxorubicin $50 \mathrm{mg}$ injection.

Median retail prices for the most-sold and lowestpriced generic versions for the four surveyed non-cancer medicines were the same. Ciprofloxacin $500 \mathrm{mg}$ had the highest price variation across all surveyed retail pharmacies (range: INR 30-49 | US\$0.41-0.67) for a pack size of 10 tablets/capsule.

\section{Private hospital pharmacies $(\mathrm{n}=2)$}

The median MPR calculated upon comparing private hospital prices with international reference prices was 0.75 for anti-neoplastic medicines and 2.34 for non-cancer medicines (see online supplementary table $2 \mathrm{~A}$ ).

Public procurement and Jan Aushadhi data

Although patients are entitled to receive free treatment in the public sector, due to poor public-sector medicine availability, they have to purchase medicines in the private sector at 1.3 times and 2.0 times the price at which the government would procure cancer and non-cancer medicines, respectively. When comparing international prices to local Indian prices, public-procurement median MPR was 0.5 for anti-neoplastic medicines and 1.0 for non-cancer medicines. The Jan Aushadhi consumer prices (for three medicines which were available on the website) were much cheaper compared with privatesector retail prices, where a patient would pay 2 times and 2.9 times in a private-sector retail pharmacy for anti-neoplastic and non-cancer medicines, respectively. See online supplementary table $3 \mathrm{~A}$.

\section{Affordability}

For patients with standard-risk B-cell precursor acute lymphoblastic leukaemia, the total cost of medicines to treat a $30 \mathrm{~kg}$ child is INR 27850 (US\$442) using the most-sold generic price (table 3) and INR 31651 (US\$502) using maximum retail prices. To buy these medicines in the private retail sector, a daily wage worker earning a minimum wage of INR 318 would have to work for 88 days (most-sold price) and 100 days (maximum retail price). For patients with high-risk B-cell precursor acute lymphoblastic leukaemia, the medicine cost goes up to INR 71428 (US\$1134), 225 days' wages (mostsold price) and INR 77476 (US\$1230), 244 days' wages (maximum retail price). For a child with early stage Hodgkin's lymphoma who weighs $30 \mathrm{~kg}$ and receives treatment using the InPOG protocol for 16 weeks of chemotherapy, the medicine cost would be INR 17500 (US\$278), 55 days' wages (most-sold price) and INR 21 364 (US\$339), 67 days' wages (maximum retail price). The same treatment for an advanced stage patient who would require treatment for up to 24 weeks would cost INR 26250 (US\$417), 83 days' wages (most-sold price) and INR 32046 (US\$509), 101 days' wages (maximum retail price). When calculated in accordance to India's 2017 per-capita income, cost of chemotherapy for standard-risk B-cell precursor acute lymphoblastic leukaemia is $23 \%$ of per-capita income and $14 \%$ for early stage Hodgkin's lymphoma. The affordability calculations would apply for those patients spending out-of-pocket, not for those receiving free or subsidised treatment. More details of cost based on most-sold generic prices can be found in online supplementary table $4 \mathrm{~A}$ to $4 \mathrm{C}$.

\section{DISCUSSION}

We found that mean availability of surveyed anti-neoplastic medicines was $70 \%$ in survey anchor areas, $38 \%$ in private retail pharmacies, $43 \%$ in public hospital pharmacies and $71 \%$ in private hospital pharmacies. The availability of anti-neoplastic medicines was lower than that of the surveyed non-cancer medicines in all facility types, except in the case of private-sector hospital pharmacies.

Since chemotherapy is administered in hospitals, hospital pharmacies should ideally stock all the medicines that are listed in the EMLc. However, these pharmacies-particularly in public hospitals-had low mean

Table 3 Cost and affordability of chemotherapy medicines needed to treat acute lymphoblastic leukaemia and Hodgkin's lymphoma

\begin{tabular}{|c|c|c|c|c|c|c|c|}
\hline Disease & $\begin{array}{l}\text { Duration of } \\
\text { chemotherapy } \\
\text { (weeks) }\end{array}$ & $\begin{array}{l}\text { Total } \\
\text { medicine } \\
\text { cost using } \\
\text { MSG prices } \\
\text { (INR) }\end{array}$ & $\begin{array}{l}\text { Total } \\
\text { medicine } \\
\text { cost using } \\
\text { MSG prices } \\
\text { (US\$) }\end{array}$ & $\begin{array}{l}\text { Days' } \\
\text { wages } \\
\text { needed } \\
\text { to pay for } \\
\text { treatment } \\
\text { medicines }\end{array}$ & $\begin{array}{l}\text { Total } \\
\text { medicine } \\
\text { cost using } \\
\text { maximum } \\
\text { retail price } \\
\text { (INR) }\end{array}$ & $\begin{array}{l}\text { Total } \\
\text { medicine } \\
\text { cost using } \\
\text { maximum } \\
\text { retail price } \\
\text { (US\$) }\end{array}$ & $\begin{array}{l}\text { Days' } \\
\text { wages } \\
\text { needed } \\
\text { to pay for } \\
\text { treatment } \\
\text { medicines }\end{array}$ \\
\hline Standard-risk BCP ALL & 120 & 27850 & 442 & 88 & 31651 & 502 & 100 \\
\hline High-risk BCP ALL & 125 & 71428 & 1134 & 225 & 77476 & 1230 & 244 \\
\hline Early stage HL & 16 & 17500 & 278 & 55 & 21364 & 339 & 67 \\
\hline Advanced stage HL & 24 & 26250 & 417 & 83 & 32046 & 509 & 101 \\
\hline
\end{tabular}

BCP ALL, B-cell precursor acute lymphoblastic leukaemia; HL, Hodgkin's lymphoma; MSG, most-sold generic. 
availability $(<80 \%)$ possibly due to poorly managed supply chain systems, inaccurate medicine demand forecasting or an underfunded public health sector in India. ${ }^{5}$ Previous studies assessing availability of medicines for chronic diseases in other settings also consistently showed lower availability of any type of brand in the public sector $(4.4 \%$ to $54 \%$ ) compared with that in the private sector. ${ }^{53-26}$ Poor availability in our surveyed private-sector retail pharmacies could be because of low demand; most private-sector hospitals do not allow patients to purchase medicines from facilities other than the pharmacy located within the hospital where a patient is being treated. ${ }^{27}$ Furthermore, physicians often prescribe medicine brands that are available in their hospital pharmacy and patients rarely have knowledge or inclination to purchase a different brand from retail pharmacies outside the hospital. In other words, poor demand for anti-neoplastic medicines and high storage costs (such as refrigeration) associated with stocking these medicines might be the reason for low availability in the private-sector retail pharmacies. Note that anti-neoplastic medicines such as prednisolone and methotrexate were widely available $(>80 \%)$, perhaps as they are also used to treat other diseases.

Similar to previous studies, ${ }^{28} 29$ our study shows there is little relevance in surveying originator brands. Generic brand versions are now more available than originator brand versions ${ }^{25} 2829$ and governments have recognised brand substitution in favour of lowering public health expenditure in hospitals. ${ }^{29}$ Moreover, most originator brands were developed more than three decades ago for childhood cancer treatment and are phased out with the increasing generic competition.

While our primary findings represent availability of strength-specific medicines, we also calculated the availability of six anti-neoplastic medicines regardless of strength. This is important since utilisation of strength-specific anti-neoplastic medicines may not be paramount, as the medicines can be diluted/reconstituted according to the patient's weight and protocol specifications. The strengths of these six medicines are recommended by the WHO EML and do not represent the entire spectrum of available strengths in the market. The true availability of any given medicine regardless of strength would be better assessed if we surveyed all strengths of the anti-neoplastic medicines available in the market, and not just the WHO EML recommendations. Hence, it is worth noting that even though 10 of the essential medicines were unavailable in strength-specific dosages in any retail/hospital pharmacy, some of them such as daunorubicin and etoposide were available in the market as $20 \mathrm{mg}$ injection and $50 \mathrm{mg}$ in eight pack size, respectively. It is possible that the demand for some of these strengths is market driven (either based on utilisation or on profit margins).

The price analysis of the medicines found that, first, originator brands were more expensive than their generic counterparts. Second, among generic versions, the most-sold and lowest-priced generic had the same consumer median price for 24 of the 27 medicines surveyed for price, indicating that the most-sold generic was often the same 'brand' as the lowest-priced generic. This could be because patients prefer to purchase the cheaper medicine versions regardless of brand image. Third, the median MPR of anti-neoplastic medicines in retail and private hospital pharmacies was less than four, indicating relatively lower local prices compared with international reference prices. This may in part be a result of the large number of generic manufacturers in India and the price regulations in force. ${ }^{142630}$

In addition, the Government of India recently launched a new initiative called Jan Aushadhi, special-discount pharmacies that aim to sell essential medicines for cheaper prices than retail. However, only three of the surveyed anti-neoplastics are on the list of medicines that are provided by these special-discount pharmacies. The government should establish an essential cancer medicines review committee to evaluate which additional medicines could be included in such schemes to improve medicine access. It is also worth noting that the surveyed pharmacies offered varying discounts on maximum retail price printed on medicine product labels, and these discount offers in part were dependent on the patient's socioeconomic status. We acknowledge there may be other economic factors that can influence medicine prices and are not assessed in this study. Our findings are in line with a study on cancer drug prices in various countries by Goldstein $e t a l,{ }^{31}$ where India had the lowest consumer prices. Furthermore, Selvaraj $e t a \hat{l}^{32}$ report that over $80 \%$ of the retail pharmacy market do not price cap, which could explain the variation in consumer prices between pharmacies for some medicines.

While prices of the surveyed medicines may be relatively low compared with international reference prices, affordability remains questionable as chemotherapy is required over a lengthy period incurring high total medicine costs. A patient with high-risk acute lymphoblastic leukaemia incurs costs of up to 244 days' wages if medicines were bought at maximum retail price. In comparison, treatment for other non-communicable diseases requires up to 3-9 days' wages to purchase 1 month's supply of required medication in India. ${ }^{25} 33$ However, this is difficult to compare with duration of cancer therapy, as treatment cannot be divided by months, but rather by cycles of recommended weeks. Our findings are in line with Selvaraj $e t a l^{32}$ which reported that total out-of-pocket spending for cancer care in both outpatient and inpatient departments was higher than other diseases in India. Another recent, as yet unpublished study on out-of-pocket expenditures of childhood cancers in India revealed that $12 \%$ of out-of-pocket in public-sector hospitals and $8 \%$ in private-sector hospitals were spent on chemotherapy costs. ${ }^{35}$ Goldstein et $a l^{31}$ also reported that cancer medicines in India were significantly less affordable compared with other countries assessed in their study. 
We acknowledge our study had some strengths and limitations which are addressed below. This study surveyed only those medicines that are used for primary chemotherapy. We do not analyse availability and affordability of the non-cancer medicines that are needed in cancer treatment nor do we factor in other associated medical and non-medical costs, such as laboratory tests or hospital admission fees. Since this was a cross-sectional study, it could not capture the pattern of medicine availability and fluctuations in medicine price over time, which would be better understood through a longitudinal study. Future research should focus on surveying the availability and price along the supply chain to understand the variations in cost at different pharmacy outlets. The findings of this study cannot be generalised to other cities of India as this survey was conducted in the national capital of India which may have better availability of medicines due to the number of tertiary care hospitals. Using the WHO/HAI methodology limits a way of assessing quality across products, which is an important area of investigation, and moreover, some of the chemotherapy medicines were unavailable on the MSH 2015 price guide. To our best knowledge, this is the first study to assess availability, price and affordability of essential medicines required to treat childhood cancers. We highlight the barriers to accessible and affordable medicines for childhood cancer treatment. Although the medicines surveyed in this study focused on childhood cancers, there is considerable overlap with the essential medicine list for adult cancers providing a unique insight into the availability of anti-neoplastic medicines in India for all age groups.

\section{CONCLUSION}

Most anti-neoplastic essential medicines were found in the survey anchor areas; however, the mean availability did not meet the WHO target of $80 \%$ availability across all facilities. While the medicine prices were relatively low compared with international reference prices, the cost of chemotherapy seems unaffordable for the lowest paid government worker in India. Low availability of essential medicines in public hospitals highlights the need for streamlining medicine procurement, distribution and supply systems. It is also important that private hospitals give more options for patients to purchase cheaper, generic medicines from retail pharmacies and government discount pharmacies. Furthermore, the government should launch initiatives across sectors to promote generic prescribing by physicians, improve price transparency and empower patients to shop around for cheaper medicine prices. With the recent launch over various government health insurance schemes, such as Ayushman Bharat, ${ }^{36}$ we recommend higher subsidies for essential medicines for cancer treatment to limit catastrophic health expenditures. Given that our study results may not be generalisable to other parts of India, we recommend further studies to evaluate the provision of and patient access to anti-neoplastic and supportive medicines, of various dosages and strengths in other Indian states. The National EML should also be updated regularly to include essential cancer medicines in line with the WHO and SIOP expert committee's guidelines. Fulfilment of these actionable recommendations will mark the first step towards ensuring access to affordable cancer treatment in India.

\section{Author affiliations}

${ }^{1}$ School of Public Health, University of Sydney, Sydney, New South Wales, Australia

${ }^{2}$ The George Institute for Global Health, Sydney, New South Wales, Australia

${ }^{3}$ Department of Global Health, Boston University School of Public Health, Boston,

Massachusetts, USA

${ }^{4}$ Precision Health Economics, Boston, Massachusetts, USA

${ }^{5}$ Independent researcher, New Delhi, India

${ }^{6}$ Cankids NGO, New Delhi, India

${ }^{7}$ Max Super Speciality Hospital, New Delhi, India

Acknowledgements We would like to thank Dr Margaret Ewen (Health Action International, Amsterdam) for her guidance on the price analysis and Mr Pawan $K$ Jaggi (Delhi State Cancer Institute, New Delhi) for information provided on the procurement data.

Contributors NF and RJ conceived the study idea. NF, RJ, RSA, AS and AM developed the research methodology with inputs from BR. NF, RSA, AS and CS planned the field survey. NF and CS conducted the data collection. NF, RSA, AS and RJ conducted the data analyses and interpretation of the results with contribution by AM and BR. NF drafted the first manuscript. NF, RJ, RSA, AS and AM revised and edited the subsequent versions of the manuscript to its final stages and approved the final manuscript.

Funding The authors have not declared a specific grant for this research from any funding agency in the public, commercial or not-for-profit sectors.

Disclaimer The views expressed in this article are of the authors and not necessarily of the institutions that they represent.

Competing interests None declared.

Patient consent for publication Not required.

Ethics approval Ethical approval for the study was obtained from The Institutional Ethics Committee for Health Related Research, Delhi, India.

Provenance and peer review Not commissioned; externally peer reviewed.

Data sharing statement № additional data are available.

Open access This is an open access article distributed in accordance with the Creative Commons Attribution Non Commercial (CC BY-NC 4.0) license, which permits others to distribute, remix, adapt, build upon this work non-commercially, and license their derivative works on different terms, provided the original work is properly cited, appropriate credit is given, any changes made indicated, and the use is non-commercial. See: http://creativecommons.org/licenses/by-nc/4.0/.

\section{REFERENCES}

1. Institute for Health Metrics and Evaluation (IHME). GBD compare Seattle, WA: University of Washington, IHME, 2016. Available: https://vizhub.healthdata.org/gbd-compare/

2. Das S, Paul DK, Anshu K, et al. Childhood cancer incidence in India between 2012 and 2014: report of a population-based cancer registry. Indian Pediatr 2017;54:1033-6.

3. Yadav SP, Rastogi N, Kharya G, et al. Barriers to cure for children with cancer in India and strategies to improve outcomes: a report by the Indian Pediatric Hematology Oncology Group. Pediatr Hematol Oncol 2014;31:217-24.

4. Arora RS, Eden TOB, Kapoor G. Epidemiology of childhood cancer in India. Indian J Cancer 2009;46:264-73.

5. Prinja S, Bahuguna P, Tripathy JP, et al. Availability of medicines in public sector health facilities of two North Indian states. BMC Pharmacol Toxicol 2015;16.

6. Chakrabarty J, Pai MS, Ranjith VK, et al. Economic burden of cancer in India. Indian J Public Health Res Dev 2017;8:137-41. 
7. Mohanti B, Mukhopadhyay A, Das S, et al. Estimating the economic burden of cancer at a tertiary public hospital: a study at the All India Institute of Medical Sciences 2011.

8. Robertson J, Magrini N, Barr R, et al. Medicines for cancers in children: the WHO model for selection of essential medicines. Pediatr Blood Cancer 2015;62:1689-93.

9. Working Group on Essential Medicines of the Pediatric Oncology in Developing Countries Committee of SIOPMehta PS, Wiernikowski JT, et al. Essential medicines for pediatric oncology in developing countries. Pediatr Blood Cancer 2013;60:889-91.

10. World Health Organization, Health Action International. Measuring medicine prices, availability, affordability and price components. 2nd edn. WHO and HAI, 2008.

11. Management Sciences for Health. International medical products price guide USA, 2016. Available: http://mshpriceguide.org/en/ home/

12. World Health Organization. Medium-term strategic plan 2008-2013. Geneva, 2008.

13. World Health Organization. Access to quality assured health products: technical briefing. Geneva: WHO, 2018.

14. Kishore SP, Basu S, Selvaraj S. Access to cancer medicines in India. Lancet Oncol 2013;14.

15. World Health Organization. WHO model list of essential medicines for children. Geneva: World Health Organization, 2017.

16. Indian Academy of Pediatrics. List of essential medicines for children of India. New Delhi, India: IAP and WHO, 2011.

17. Government of India, World Health Organization. National Essential Medicines List-India, 2015. Available: http://apps.who.int/ medicinedocs/en/d/Js23088en/

18. Government of Delhi. Essential medicines list 2016 Delhi, India, 2016. Available: http://www.delhi.gov.in/wps/wcm/connect/abdb 54804c877076b665b7dd63b32208/EML2016_draft.pdf?MOD= AJPERES\&Imod=296430078

19. Sharma A, Rorden L, Ewen M, et al. Evaluating availability and price of essential medicines in Boston area (Massachusetts, USA) using WHO/HAl methodology. J Pharm Policy Pract 2016;9.

20. Bureau of Pharma PSUs of India. Jan Aushadhi scheme India: Government of India, 2018. Available: janaushadhi.gov.in

21. Government of India. Chief labour commissioner (Central): minimum wages New Delhi, 2018. Available: https://clc.gov.in/clc/min-wages

22. World currency exchange rates and currency exchange rate history. exchange-rates.org, 2018. Available: https://www.exchange-rates. org/Rate/USD/INR/1-5-2018

23. van Mourik MSM, Cameron A, Ewen M, et al. Availability, price and affordability of cardiovascular medicines: a comparison across 36 countries using WHO/HAI data. BMC Cardiovasc Disord 2010;10.
24. Mendis S, Fukino K, Cameron A, et al. The availability and affordability of selected essential medicines for chronic diseases in six low- and middle-income countries. Bull World Health Organ 2007;85:279-88.

25. Kotwani A. Where are we now: assessing the price, availability and affordability of essential medicines in Delhi as India plans free medicine for all. BMC Health Serv Res 2013;13.

26. Cameron A, Ewen M, Ross-Degnan D, et al. Medicine prices, availability, and affordability in 36 developing and middle-income countries: a secondary analysis. Lancet 2009;373:240-9.

27. The Indian Express. Allow patients to buy medicines from outside: health panel to private hospitals Kolkata, India, 2018. Available: https://indianexpress.com/article/cities/kolkata/allow-patients-tobuy-medicines-from-outside-health-panel-to-private-hospitals5110875/

28. Jiang M, Yang S, Yan K, et al. Measuring access to medicines: a survey of prices, availability and affordability in Shaanxi Province of China. PLoS One 2013;8:e70836.

29. Xi X, Li W, Li J, et al. A survey of the availability, prices and affordability of essential medicines in Jiangsu Province, China. BMC Health Serv Res 2015;15.

30. Dhamija P, Sharma PK, Kalra S. Only generics (drugs/names): is India ready? Indian J Endocrinol Metab 2015;19:541-5.

31. Goldstein DA, Clark J, Tu Y, et al. A global comparison of the cost of patented cancer drugs in relation to global differences in wealth. Oncotarget 2017;8:71548-55.

32. Selvaraj S, Farooqui HH, Karan A. Quantifying the financial burden of households' out-of-pocket payments on medicines in India: a repeated cross-sectional analysis of National Sample Survey data, 1994-2014. BMJ Open 2018;8.

33. Gelders S, Ewen M, Noguchi N, et al. Price, availability and affordability: an international comparison of chronic disease medicines. Cairo: World Health Organization and Health Action International, 2006

34. Sharma A, Kaplan WA. Challenges constraining access to insulin in the private-sector market of Delhi, India. BMJ Glob Health 2016;1.

35. Arora R, Rahman RU, Joe W, et al. Families of children newly diagnosed with cancer Incur significant out-of-pocket expenditure for treatment: report of a multi-site prospective longitudinal study from India (INPOG-ACC-16-01). J Glob Oncol 2018;4(Supplement 2).

36. Goverment of India. Ayushman Bharat National health protection mission: national portal of India, 2019. Available: https://www. india.gov.in/spotlight/ayushman-bharat-national-health-protectionmission 